\title{
Beta Adrenergic Receptor
}

National Cancer Institute

\section{Source}

National Cancer Institute. Beta Adrenergic Receptor. NCI Thesaurus. Code C17062.

Expressed by Beta Adrenergic Receptor Genes in effector tissues innervated by postgang lionic sympathetic adrenergic fibers, Beta Adrenergic Receptors are one of two major classes of adrenergic receptors (alpha and beta) based on their reactions to norepinephrine and epinephrine, on cellular effects of receptor activation, and on relative affinities and reactions to synthetic blocking or stimulating agents. Beta-adrenergic receptors respond to blocking agents such as propranolol and to activating agents such as isoproterenol. Beta-1 type receptors mediate lipolysis and increase cardiac rate and force of contraction; beta-2 type receptor activation promotes bronchial and vascular smooth muscle relaxation. When coupled to adenylate cyclase through Gs protein, Beta Adrenergic Receptor stimulation results in increased intracellular cyclic AMP. (NCI) 